\title{
VANHEMMUUTEEN LIITTYVÄT HUOLENAIHEET JA PSYYKKINEN HYVINVOINTI NEUROPSYKIATRISESTI OIREILEVIEN LASTEN HUOLTAJILLA
}

\section{Johdanto}

Vanhemmuuteen liittyviä huolenaiheita esiintyy monissa lapsiperheissä (Östberg \& Hagekull 2000; Perälä ym. 2011; Halme \&t Perälä 2014). Lievä huolestuneisuus saattaa vahvistaa aikuisen herkkyyttä tunnistaa lapsen tarpeita. Vanhemmuuteen liittyvä merkittävä huoli on sen sijaan erityinen psyykkisen kuormittuneisuuden muoto, joka viittaa lapsen ja huoltajan välisen suhteen haasteisiin (Deater-Deckard 1998). Lapsen psyykkisen ja neuropsykiatrisen oireilun on havaittu lisäävän myös huoltajien mielialaoireita (Barlow ym. 2012). Huoltajan psyykkinen kuormittuneisuus saattaa puolestaan lisätä kielteistä reagointia lapsen haastavaan käyttäytymiseen (Karst \& Van Hecke 2012; Hayes \&t Watson 2013), mikä ylläpitää lapsen ja huoltajan keskinäisen vuorovaikutuksen ja lapsen käyttäytymisen ongelmia (Johnston \& Mash 2001; Kawabata ym. 2011; Faraone ym. 2015). Näistä syistä huoltajien hyvinvointia estävät tekijät tulee huomioida neuropsykiatrisesti oireilevien lasten hoidon suunnittelussa ja toteutuksessa (ADHD: Käypä hoito -suositus 2017).

Huoltajien hyvinvoinnin vahvistaminen on erityisen tärkeää niissä perheissä, joissa lapset tarvitsevat toimintakykynsä tueksi tavallista intensiivisempää hoitoa ja kuntoutusta. Lapsen kliinisesti merkittävän neuropsy- kiatrisen oireilun, esimerkiksi aktiivisuuden ja tarkkaavuuden häiriön (ADHD), yhteydessä esiintyy usein samanaikaisia tunteiden ja käyttäytymisen säätelyn vaikeuksia (Kanne Ct Mazurek 2011; Frick \&t Nigg 2012; Faraone ym. 2015; Vuori ym. 2017). Aikaisemmissa tutkimuksissa on havaittu, että lapsen neuropsykiatrisen oireilun yhteydessä esiintyvät samanaikaiset uhmakkuus- ja käytösoireet ovat yhteydessä huoltajien kokemaan voimakkaampaan psyykkiseen kuormittuneisuuteen, kun heitä on verrattu huoltajiin, joiden lapsilla esiintyy ainoastaan neuropsykiatrisia ydinoireita (Johnston \&t Mash 2001; Deault 2010; Kippola-Pääkkönen ym. 2016). Aikaisemmissa tutkimuksissa on myös havaittu, että poikien vanhemmat tuovat voimakkaammin esille vanhempana toimimiseen liittyviä haasteita kuin tyttöjen vanhemmat. Lapsen iän ei sen sijaan havaittu kliinisten tutkimusaineistojen meta-analyysissa olevan yhteydessä vanhempien kokemiin kasvatushaasteisiin. (Theule ym. 2013.) Äitien ja isien keskinäiset vertailut ovat osoittaneet, että huoli vanhemmuudesta ja psyykkinen kuormittuneisuus ovat äideillä voimakkaampia kuin isillä (Karst \&t Van Hecke 2012; Hinshaw ym. 2015).

Perhelähtöisten psykososiaalisten hoitomuotojen - erityisesti strukturoidun vanhem- 
painohjauksen - on havaittu vähentävän lasten tunteiden säätelyn ja käyttäytymisen ongelmia (Sanders ym. 2014; Fabiano ym. 2015), vanhemmuuteen liittyviä huolia (Battagliese ym. 2015) ja huoltajien mielialaoireita (Barlow ym. 2012; Furlong ym. 2012). Vanhempainohjaus myös vahvistaa myönteisiä kasvatuskäytäntöjä (Daley ym. 2014; Sanders ym. 2014). Toisaalta huoltajien hyvinvointia estävien tekijöiden tunnistaminen hoitoa suunniteltaessa on tärkeää, sillä huoltajien psyykkisen kuormittuneisuuden on havaittu heikentävän heidän hoitoon sitoutumistaan ja hoidon tuloksellisuutta (Menting ym. 2013; Hinshaw ym. 2015). Perheet voivat hyötyä erityisesti haastavissa tilanteissa yksilöllistetystä tuesta, jossa yhdistyvät vanhempainohjaus ja huoltajien tarpeet huomioiva yksilö- ja perheterapeuttinen työskentely (Chronis ym. 2007; Weisz Et Kazdin 2010; Battagliese ym. 2015; Bearss ym. 2015; Bjørnebekk ym. 2015; Lindhiem ym. 2016; Ng \&t Weisz 2016). Tämä havainto on tehty myös ADHD:n psykosososiaalisen hoidon suosituksiin merkittävästi vaikuttaneessa pohjoisamerikkalaisessa MTA-seurantatutkimuksessa (Multimodal Treatment of ADHD Study; ks. Hinshaw ym. 2015). Kotimainen ADHD:n hoitosuositus korostaakin monimuotoisen tuen tärkeyttä lapsen ADHD:n hoidossa (ADHD: Käypä hoito -suositus 2017).

Tämän tutkimuksen tavoitteena on selvittää monimuotoiseen perhekuntoutukseen ohjattujen lasten huoltajien kokemia, vanhempana toimimiseen liittyviä huolenaiheita ja psyykkistä kuormittuneisuutta lasten hoidon alkaessa. Lähtökohtana on, että lapsen ja huoltajan keskinäiseen vuorovaikutukseen yhteydessä olevat haasteet ovat perhelähtöiseen hoitoon hakeutumisen ja ohjautumisen taustalla (Theule ym. 2013; Karjalainen ym. 2016). Tutkimuksella etsitään vastauksia seuraaviin kysymyksiin:

1) Kuinka yleisiä vanhemmuuteen liittyvät huolet ovat monimuotoiseen perhekuntoutukseen ohjattujen lasten huoltajilla?

2) Kuinka yleistä on huoltajien mielialaoireilu?

3) Mitkä lapsi-, huoltaja- ja perhekohtaiset tekijät selittävät vanhemmuuteen liittyvien huolten vaihtelua?

4) Kuinka voimakasta on vanhemmuuteen liittyvien huolten yhteys huoltajien psyykkiseen kuormittuneisuuteen?

Oletamme, että omasta vanhemmuudesta koettu huoli on voimakkaampaa kliinisessä tutkimusaineistossamme kuin yleisväestölle suunnatuissa perhetutkimuksissa. Merkittävän huolestuneisuuden esiintyvyys (esimerkiksi syyllisyyden ja riittämättömyyden tunne vanhempana sekä maltin menettäminen ristiriitatilanteissa lapsen kanssa) on lapsiperhekyselyissä ollut noin 3-7 prosenttia (Perälä ym. 2011; Halme \&t Perälä 2014). Saman perheen huoltajien keskinäisten erojen ei oleteta muodostuvan suuriksi. Sen sijaan lapsen uhmakkuus- ja käytösoireiden oletetaan olevan yhteydessä huoltajien voimakkaampaan huoleen vanhemmuudestaan (Johnston \& Mash 2001; Deault 2010). Merkittävän vanhemmuuteen liittyvän huolen oletetaan lisäksi heikentävän huoltajien kokemaa hyvinvointia laajemmin (Barlow ym. 2012; Theule ym. 2013).

\section{Aineisto ja menetelmät}

\section{Tutkimusongelma}

Kelassa on käynnissä vuosina 2010-2018 monimuotoisen perhekuntoutuksen kehittämistyö. Perhekuntoutukseen ohjatuilla (5-12-vuotiailla) lapsilla on diagnosoitu neuropsykiatrinen häiriö ja mahdollisesti samanaikaisia tunne-elämän ja käyttäytymisen häiriöitä. Lapsilla tulee olla pitkäkestoisen tuen tarve, ja perheiden tulee olla sitoutuneita kuntoutukseen. Poissulkukriteerejä ovat akuuttia sairaalahoitoa vaativa lapsen psyykkinen oireilu, huoltajan vakava päihdeongelma tai lastensuojelun toimenpiteet (lapsen sijoittaminen kodin ulkopuolelle).

\section{Hoito-ohjelmien kuvaus}

Perhekuntoutuksen kesto on 12 kuukautta (LAKU) tai 18 kuukautta (Etä-LAKU). LAKUhoito-ohjelmassa lapsia ja perheitä voidaan 
tavata palveluntuottajan toimipisteessä tai kotona. Etä-LAKU-hoito-ohjelmaa tarjotaan haja-asutusalueilla asuville lapsille ja perheille, ja työntekijät jalkautuvat poikkeuksetta perheiden kotiin. Hoito-ohjelmat sisältävät perhetapaamisia ja vanhempainohjausta (14-18 tapaamiskertaa), lapsen yksilötapaamisia (913 tapaamiskertaa) ja lähettävän tahon sekä päiväkodin tai koulun kanssa tehtävää yhteistyötä (7 tapaamiskertaa). Erilliset perheviikonloput (korkeintaan kaksi viikonloppua) hoito-ohjelman aikana mahdollistavat vertaistukeen ja toiminnallisiin elementteihin perustuvan työskentelyn. Lisäksi LAKU-ohjelma sisältää mahdollisuuden erilliseen psykoedukatiiviseen vanhempainryhmään (10 tapaamista), mutta tämä puuttuu etämallista. Kuntoutusta voidaan jatkaa lisäkäynneillä (10-15 tapaamista), jolloin kokonaiskesto on noin 24 kuukautta. Toteutus on kansallisen hoitosuosituksen mukaisesti monimuotoista (ADHD: Käypä hoito -suositus 2017). Toimintasisällöissä on havaittavissa tiettyä samankaltaisuutta kansainvälisiin hoitomalleihin verrattuna, mutta LAKU- ja Etä-LAKU-hoito-ohjelmien muutosteoriaa ja sisältöä ei ole määritelty yhtä täsmällisesti kuin empiirisesti tuetuissa hoitomalleissa (Weisz ja Kazdin 2010; Battagliese ym. 2015; Hinshaw ym. 2015). Intervention kuvaus on esitetty myös Kelan kehittämistoiminnan verkkosivuille ladatussa hankesuunnitelmassa (http://www.kela.fi/neuropsykiatrinenkuntoutus).

\section{Tutkimusasetelma ja aineisto}

Kyseessä on praktinen havaintotutkimus, joka käynnistettiin vuoden 2013 syksyllä. Kahteen aktiiviseen perhekuntoutuksen hoitoohjelmaan osallistuneista perheistä kerättiin harkinnanvaraiset näytteet (March ym. 2005). Tutkimuksen toteutus on kuvattu tarkemmin protokolla-artikkelissa (Vuori ym. 2015). Tämän artikkelin tutkimusaineiston muodostavat hoito-ohjelmiin ohjattujen lasten huoltajille suunnatut aloituskyselyt. Hoito-ohjelmiin ohjattiin tutkimukseen rekrytoinnin aikana yhteensä 232 perhettä, joista 30 kieltäytyi tutkimuksesta (kuvio 1). Neljä perhettä keskeytti kuntoutuksen jo alkuvaiheessa. Loput puuttuvat havainnot selittyvät yksittäisillä kieltäytymisillä ja etenkin perhemuotojen eroilla. Tutkimusaineistossamme on mukana 186 äitiä ja 144 isää yhteensä 198 perheestä.

Tutkimusaineiston lasten keski-ikä oli 8,9 vuotta $(\mathrm{kh}=1,9)$. Tutkimukseen osallistuneista lapsista 15 prosenttia oli tyttöjä $(n=29)$ ja 85 prosenttia poikia $(n=169)$. Tyttöjen ja poikien keski-iät eivät eronneet toisistaan. Lasten diagnoosit perustuvat ICD-10-luokitukseen. Suurimman ryhmän muodostivat lapset, joilla oli diagnosoitu ADHD (54\%, $\mathrm{n}=$ 106). Toiseksi suurimman ryhmän (19\%, $n=$ 37) muodostivat lapset, joilla oli diagnosoitu ADHD:n lisäksi uhmakkuus- tai käytöshäiriö tai hyperkineettinen käytöshäiriö. Noin joka kuudennella aineistomme lapsella (16\%, $\mathrm{n}=$ 31) oli diagnosoitu laaja-alainen kehityshäiriö. Aineiston pienestä koosta johtuen ryhmään muut häiriöt luokiteltiin kuuluvaksi ne lapset ( $11 \%, n=23)$, joilla oli päädiagnoosina esimerkiksi monimuotoinen kehityshäiriö, lapsuudessa tai nuoruudessa alkava sosiaalisen vuorovaikutuksen häiriö tai nykimishäiriö. Kahteen eri hoito-ohjelmaan ohjattujen lasten ikä-ja sukupuolijakaumat ja diagnoosiryhmien vaihtelu eivät eronneet toisistaan aineistossamme. Tutkimukseen osallistuneiden äitien keski-ikä $(38,5$ vuotta, $\mathrm{kh}=6,0)$ oli tilastollisesti merkitsevästi ( $p=0,001)$ alhaisempi kuin isien keski-ikä (40,7 vuotta, kh =6,7).

\section{Vanhemmuuteen liittyviä huolia mittaavat osiot}

Vanhemmuuteen liittyviä huolenaiheita mitattiin viiden osion avulla Terveyden ja Hyvinvoinnin laitoksen (THL) ja Tilastokeskuksen toteuttamia lapsiperhekyselyjä hyödyntäen (Perälä ym. 2011; Halme \&t Perälä 2014). Tutkittavilta tiedusteltiin neliportaisilla asenneväittämillä, missä määrin seuraavat vanhemmuuteen liittyvät huolenaiheet "kuvaavat heidän viimeaikaisia kokemuksiaan": (a) oma jaksaminen; (b) johdonmukainen rajojen asettaminen lapselle; (c) maltin menettäminen ristiriitatilanteissa lapsen kanssa; (d) jatkuva syyllisyyden ja riittämättömyyden tunne van- 
Kuvio 1. Tutkimusaineiston $(\mathrm{N}=198$ perhettä) muodostuminen.

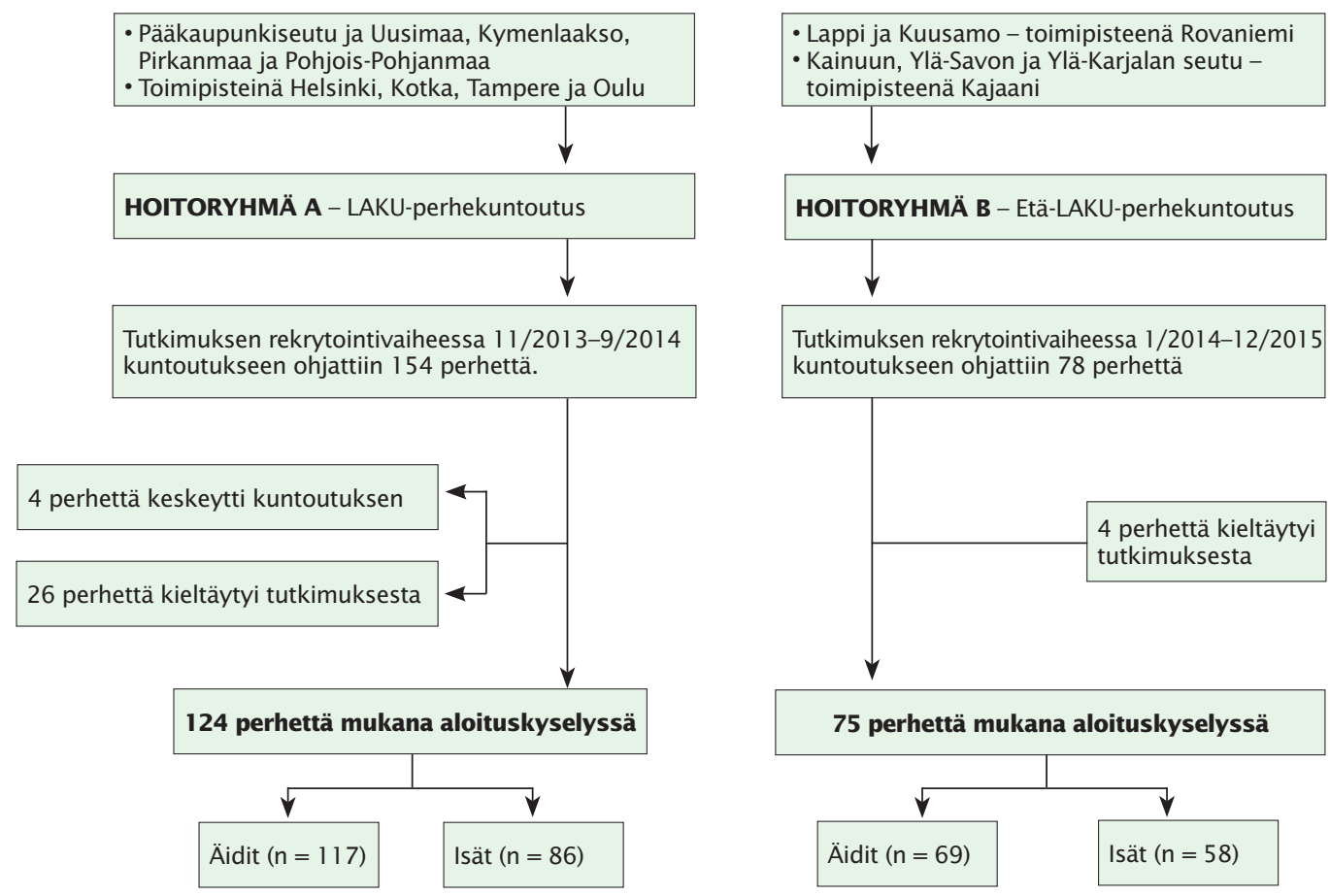

Huom. Äiti ja isä tarkoittavat tässä tutkimuksessa lapsen biologista vanhempaa tai äiti-/isäpuolta.

hempana, ja (e) yksinäisyys ja vastuun kantaminen yksin vanhempana, $(1$ = "en ole ollut lainkaan huolissani", 2 = "olen ollut vähän huolissani", 3 = "olen ollut melko paljon huolissani", 4 = "olen ollut erittäin huolissani"). Huoli on inhimilliseen elämään kuuluva ilmiö, mutta intensiteetiltään voimakkaamman huolen (arvot 3-4) katsotaan kertovan merkittävästä vanhemmuuteen liittyvästä huolesta (Theule ym. 2013; Gladstone \&t Parker 2003).

\section{Huoltajien psyykkistä hyvinvointia mittaavat osiot}

Huoltajien psyykkistä kuormittuneisuutta kartoitettiin viisi osiota sisältävällä Mental Health Inventory:lla (MHI-5). MHI-5 on standardoitujen elämänlaatukyselyjen pohjalta kehitetty aikuisten psyykkistä hyvinvointia ja mielialaa kartoittava geneerinen mittari. (Kelly ym. 2008.) MHI-5 ei siis ole oirespesifı mutta soveltuu aikaisempien tutkimusten perusteella erityisesti mielialaoireiden kartoittamiseen
(Vester Thorsen ym. 2013). Osioiden yhteenlaskettu summapistemäärä muutettiin ohjeiden mukaisesti asteikolle 0-100. Matalammat arvot viittaavat psyykkiseen kuormittuneisuuteen (Kelly ym. 2008). MHI-5:n luokittelukykyä tarkastelevat tutkimukset ovat tuottaneet erilaisia raja-arvoa, joten MHI-5:n käyttö tutkimuksessa vaihtelee (Kelly ym. 2008; Vester Thorsen ym. 2013). THL:n Alueellisessa terveys- ja hyvinvointitutkimuksessa (ATH) kliinisesti merkittävän psyykkisen kuormittuneisuuden raja-arvo on 52 pistettä. Tämä on todennäköisesti yleisimmin käytetty katkaisukohta (Vester Thorsen ym. 2013; Murto ym. 2017). Toisaalta kansainvälisissä tutkimuksissa on hyödynnetty myös useampia katkaisukohtia. Esimerkiksi 60 ja 68 pisteen raja-arvot tavoittavat aikaisempien tutkimusten perusteella myös lievän mielialaoireilun (Yamazaki ym. 2005; Vester Thorsen ym. 2013). Tästä syystä tutkimusaineistomme kuvauksessa hyödynnetään kolmea katkaisukohtaa: $\leq$ 52, $\leq 60$ ja $\leq 68$. Mittarin reliabiliteetti oli tutki- 
musaineistossamme korkea (Cronbachin $\mathrm{a}=$ $0,86)$. Osiot korreloivat voimakkaasti mittarin kokonaispistemäärän kanssa [0,60-0,76].

Koettua elämänlaatua mitattiin WHO8EUROHIS-mittarin yleiskysymyksen avulla: "Millaiseksi arvioit elämänlaatusi?" Vastausvaihtoehtoja oli yhteensä viisi $(1=$ "erittäin huono", 2 = "huono", 3 = "kohtalainen", 4 = "hyvä", 5 = "erittäin hyvä"). Yksinäisyyden indikaattori perustuu yleiskysymykseen: "Tunnetko itsesi yksinäiseksi?" Vastausvaihtoehtoja oli yhteensä viisi ( 1 = "en koskaan", 2 = "hyvin harvoin", 3 = "joskus", 4 = "melko usein", 5 = "erittäin usein"). Edellä luetellut osiot ovat mukana myös Alueellisessa terveys- ja hyvinvointitutkimuksessa (Murto ym. 2017). Subjektivista ahdistuneisuutta mitattiin Raimo Raitasalon Suomen oloihin kehittämään depressiokyselyyn sisältyvällä yksittäisellä osiolla. Subjektiivista ahdistuneisuutta mitattiin väittämällä: "Oletko mielestäsi yleensä ahdistunut tai jännittynyt?" Muuttuja perustuu viisiportaiseen asteikkoon. Ahdistuneisuutta kuvaava dikotominen muuttuja muodostettiin ohjeistuksen mukaisesti: $0=$ ei ahdistunut ("Pidän itseäni melko hyvähermoisena enkä ahdistu kovinkaan helposti", "En tunne itseäni ahdistuneeksi tai huonohermoiseksi"), 1 = ahdistunut ("Ahdistun tai jännityn melko helposti", "Tulen erityisen helposti tuskaiseksi, ahdistuneeksi tai jännittyneeksi”, "Tunnen itseni jatkuvasti ahdistuneeksi ja tuskaiseksi, kuin hermoni olisivat loppuun kuluneet”; ks. Raitasalo 2007).

\section{Kontrollimuuttujat}

Vanhemmuuden huolten vaihtelua selittäviä lapsikohtaisia kontrollimuuttujia tutkimuksessa olivat lapsen ikä, sukupuoli ja ICD-10-tautiluokituksen diagnoosien pohjalta muodostetut neljä diagnoosiryhmää. Muita lapsikohtaisia kontrollimuuttujia olivat huoltajan ilmoittama lapsen oireiden ilmaantumisikä ja mahdollinen lääkehoito. Hoitohistorian osalta huomioitiin huoltajan ilmoittamat erikoissairaanhoidon osastohoitojaksot ja lastensuojelun perhetyö. Huoltaja- ja perhekohtaisia kontrollimuuttujia olivat huoltajan ikä ja perhemuoto (ydinperhe, uusperhe ja yksinhuoltaja). Interventiotason kontrollimuuttujana on käytetty hoito-ohjelman tyyppiä (LAKU versus Etä-LAKU).

\section{Aineiston analysointi}

Analyysit suoritettiin käyttäen SPSS-tilastoohjelman versiota 23. Kolme henkilöä ei ollut vastannut vanhemmuuteen liittyviä huolia mittaaviin osioihin, joten nämä havaintoyksiköt jätettiin pois lopullisista analyyseista. Puuttuvia arvoja ei imputoitu. Analyysimenetelminä käytettiin Pearsonin riippumattomuustestiä $\left(\chi^{2}\right)$ ja hierarkkista lineaarista regressioanalyysia (HLM). HLM on rqegressioanalyysin laajennus, jossa huomioidaan se, että yksittäiset havainnot - tässä tapauksessa huoltajat samasta perheestä - muodostavat klustereita ja hiearkkisen aineistorakenteen. Havaintoyksiköiden riippumattomuusoletus ryhmien sisällä ei täyty, mikä tulee huomioida mallinnuksessa. (Garson 2013.) Havaintoyksiköiden samankaltaisuutta ryhmän sisällä tarkasteltiin sisäkorrelaation (Intraclass correlation = ICC) avulla, joka vaihtelee välillä 0-1. Tämän tutkimuksen kontekstissa ICC on tulkittavissa siten, että kun sisäkorrelaatio on 1, samojen perheiden äidit ja isät ovat arvioineet itsensä täysin samankaltaisiksi vanhemmuuteen liittyvän huolestuneisuuden osalta. Vanhemmuuteen liittyvien huolten vaihtelu selittyy tässä tapauksessa ryhmien (perheiden) välisillä eroilla. Mikäli sisäkorrelaatiota ei havaita lainkaan (ICC = 0), samojen perheiden äitien ja isien arvioiden välillä ei havaita keskinäistä lineaarista riippuvuutta. Kyseessä on tällöin yksilötason ilmiö. (Ellonen 2008; Garson 2013.) Tämän lisäksi tutkimuksessa analysoitiin vanhemmuuteen liittyvien huolten yhteyttä huoltajien psyykkiseen hyvinvointiin korrelaatiotarkastelujen $(r$ $=$ Pearsonin tulomomenttikorrelaatio) avulla Korrelaatiotarkastelut tehtiin äideille ja isille erikseen.

\section{Eettiset huomiot}

Tutkimuksella on Kelan tutkimuseettisen toimikunnan puoltava lausunto. Tutkimus on re- 
Taulukko 1. Tutkimusaineiston huoltajien kokemat vanhemmuuteen liittyvät huolenaiheet.

\begin{tabular}{|c|c|c|c|c|c|}
\hline & $\begin{array}{l}\text { "En ole ollut } \\
\text { lainkaan } \\
\text { huolissani" }\end{array}$ & $\begin{array}{l}\text { "Olen ollut } \\
\text { vähän } \\
\text { huolissani" }\end{array}$ & $\begin{array}{l}\text { "Olen ollut } \\
\text { melko paljon } \\
\text { huolissani" }\end{array}$ & $\begin{array}{c}\text { "Olen ollut } \\
\text { erittäin } \\
\text { huolissani" }\end{array}$ & $\begin{array}{c}\chi^{2} \text { (df) } \\
(p-a r v o)\end{array}$ \\
\hline \multicolumn{6}{|c|}{$\%(n)$} \\
\hline Oma jaksaminen & & & & & \\
\hline Huoltajat yhteensä, $n=326$ & $21,2 \%(69)$ & $48,2 \%(157)$ & $23,9 \%(78)$ & $6,7 \%(22)$ & \\
\hline Äidit, $\mathrm{n}=185$ & $12,4 \%(23)$ & $49,7 \%(92)$ & $27,6 \%(51)$ & $10,3 \%(19)$ & \multirow{2}{*}{$\begin{array}{l}\chi^{2}=25,86_{(3)} \\
(p<0.0001)\end{array}$} \\
\hline Isät, $n=141$ & $32,7 \%(46)$ & $46,1 \%(65)$ & $19,1 \%(27)$ & $2,1 \%(3)$ & \\
\hline $\begin{array}{l}\text { Rajojen asettaminen } \\
\text { Huoltajat yhteensä, } n=326\end{array}$ & $34,7 \%(113)$ & $46,9 \% 153)$ & $16,9 \%(55)$ & $1,5 \%(5)$ & \\
\hline Äidit, $\mathrm{n}=185$ & $30,8 \%(57)$ & $46,5 \%(86)$ & $21,1 \%(39)$ & $1,6 \%(3)$ & \multirow{2}{*}{$\begin{array}{l}\chi^{2}=6,14 a_{(3)} \\
(p=0,0464)\end{array}$} \\
\hline Isät, $n=141$ & $39,7 \%(56)$ & $47,5 \%(67)$ & $11,3 \%(16)$ & $1,4 \%(2)$ & \\
\hline $\begin{array}{l}\text { Maltin menettäminen } \\
\text { Huoltajat yhteensä, } n=326\end{array}$ & $26,1 \%(85)$ & $48,5 \%(158)$ & $19,0 \%(62)$ & $6,4 \%(21)$ & \\
\hline Äidit, $\mathrm{n}=185$ & $21,1 \%(39)$ & $49,2 \%(91)$ & $20,5 \%(38)$ & $9,2 \%(17)$ & \multirow{2}{*}{$\begin{array}{l}\chi^{2}=9,6_{(3)} \\
(p=0,0216)\end{array}$} \\
\hline Isät, $n=141$ & $32,5 \%(46)$ & $47,5 \%(67)$ & $17,0 \%(24)$ & $2,8 \%(4)$ & \\
\hline \multicolumn{6}{|l|}{ Syyllisyyden tunne } \\
\hline Huoltajat yhteensä, $n=326$ & $14,4 \%(47)$ & $44,5 \%(145)$ & $27,6 \%(90)$ & $13,5 \%(44)$ & \\
\hline Äidit, $n=185$ & $9,2 \%(17)$ & $37,2 \%(69)$ & $34,1 \%(63)$ & $19,5 \%(36)$ & \multirow{2}{*}{$\begin{array}{l}\chi^{2}=30,77_{(3)} \\
(p<0.0001)\end{array}$} \\
\hline Isät, $n=141$ & $21,3 \%(30)$ & $53,9 \%(76)$ & $19,1 \%(27)$ & $5,7 \%(8)$ & \\
\hline $\begin{array}{l}\text { Yksinäisyys huoltajana } \\
\text { Huoltajat yhteensä, } n=326\end{array}$ & $51,2 \%(167)$ & $29,8 \%(97)$ & $14,1 \%(46)$ & $4,9 \%(16)$ & \\
\hline Äidit, $n=185$ & $36,2 \%(67)$ & $36,2 \%(67)$ & $20,0 \%(37)$ & $7,6 \%(14)$ & \multirow{2}{*}{$\begin{array}{l}\chi^{2}=41,50_{(3)} \\
(p<0.0001)\end{array}$} \\
\hline Isät, $n=141$ & $70,9 \%(100)$ & $21,3 \%(30)$ & $6,4 \%(9)$ & $1,4 \%(2)$ & \\
\hline
\end{tabular}

Äitien ja isien jakaumavertailut on toteutettu Pearsonin $\chi^{2}$-yhteensopivuustestillä ( $\mathrm{df}=$ vapausasteet). Huom. a "melko paljon" ja "erittäin paljon" huolestuneiden ryhmät yhdistetty toisiinsa Pearsonin $\chi^{2}$-yhteensopivuustestin laskemista varten.

kisteröity yleisesti hyväksyttyyn tietokantaan (ClinicalTrials.gov \# NCT02250339).

\section{Tulokset}

\section{Vanhemmuuteen liittyvät huolet}

Vanhemmuuteen liittyvien huolten jakaumissa ei havaittu eroja hoito-ohjelmien (LAKU ja Etä-LAKU) välillä, joten tulokset on esitetty koko tutkimusaineistolle ja äideille sekä isille erikseen (taulukko 1). Tulosten mukaan valtaosa tutkimusaineiston äideistä ja isistä ilmaisi vanhemmuuteen liittyviä huolenaiheita, mutta huolet olivat pääsääntöisesti korkeintaan lieviä ("olen ollut vähän huolissani"). Noin puolet tutkimusaineiston äideistä ja neljäsosa isistä ilmaisi vähintään melko paljon syyllisyyden ja riittämättömyyden tunteeseen liittyvää huolta. Toiseksi yleisintä äideillä (38\%) ja isillä $(21 \%)$ oli huoli omasta jaksamisesta neuropsykiatrisesti oireilevan lapsen vanhempana. Vajaa kolmasosa aineistomme äideistä (30\%) ja noin joka viides isistä $(20 \%)$ oli vähintäänkin melko paljon huolissaan lapsen kanssa esiintyvien ristiriitatilanteiden yhteydessä esiintyvästä oman maltin menettämisestä. Huoltajien keskinäisiä eroja tarkasteltiin ristiintaulukoinnin avulla. $\chi^{2}$-riippumattomuustestin tulokset on esitetty taulukon 1 viimeisessä sarakkeessa. Tulokset osoittivat, että äitien ja isien huolten jakaumat poikkesivat tilastollisesti merkitsevästi toisistaan.

Seuraavaksi tarkastelimme vanhemmuuteen liittyvien huolten kumuloitumista (kuvio 2). Edellä esitettyjen yksittäisten osioiden "ei lainkaan" ja "vähän" huolestuneiden osuudet saivat arvon 0. Merkittävää huolta ilmaisseet vastaajat ("melko paljon" ja "erittäin paljon" huolestuneet) saivat arvon 1. Vanhemmuuteen 


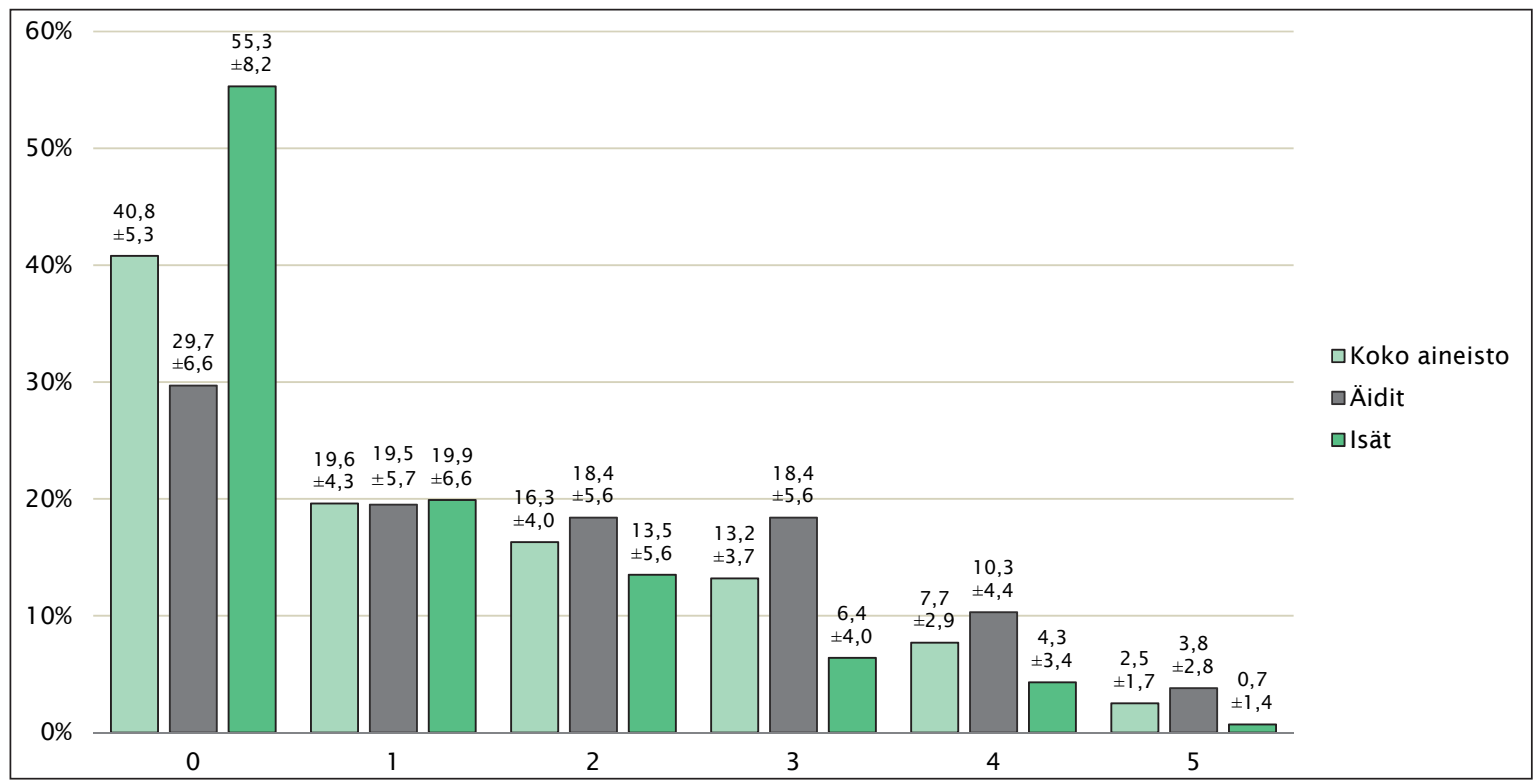

Kuvio 2. Vanhemmuuteen liittyvän merkittävän huolen kumuloituminen (prosenttiosuudet).

Merkittävä huoli koostuu "melko paljon" ja "erittäin paljon" huolestuneiden vastaajien kumulatiivisesta jakaumasta (vaihteluväli 0-5). Kuviossa on esitetty myös prosenttiosuuksille lasketut 95 \%:n luottamusvälit.

liittyvän merkittävän huolen kumuloituminen vaihteli täten välillä $0-5$. Tulosten mukaan vajaalla kolmasosalla tutkimukseen osallistuneista äideistä (30 \%) ja enemmistöllä isistä (55\%) ei esiintynyt merkittävää vanhemmuuteen liittyvää huolta. Toisaalta noin viidesosalla äideistä ja isistä korostui yksi merkittävä vanhemmuuteen liittyvä huolenaihe. Reilulla neljäsosalla äideistä ja viidesosalla isistä puolestaan esiintyi 2-3 samanaikaista vanhemmuuteen liittyvää merkittävää huolta. Huolten voimakas kumuloituminen (4-5 huolta) oli vähäisempää. On kuitenkin huomionarvoista, että 14 prosenttia tutkimusaineiston äideistä ja 5 prosenttia isistä ilmaisi laaja-alaisesti merkittävää vanhemmuuteen liittyvää huolta.

\section{Huoltajien psyykkinen hyvinvointi}

Huoltajien psyykkisen hyvinvoinnin jakaumissa ei havaittu eroja hoito-ohjelmien välillä, joten tulokset esitetään jälleen koko tutkimusaineistolle ja huoltajien mukaan eriteltyinä. Tutkimushavainnot antoivat viitteitä siitä, että noin 17 prosentilla äideistä ja 11 prosentilla isistä saattaa olla kliinisesti merkittävää mielialaoireilua (MHI-5, $\leq 52$ pistettä) (taulukko 2). Käytettäessä 52 pisteen raja-arvoa äitien ja isien psyykkisen kuormittuneisuuden jakaumat eivät poikenneet toisistaan $\left(\chi_{(1)}^{2}=\right.$ $2,29, \mathrm{p}=0,15)$. Sen sijaan tarkasteltaessa huoltajien psyykkistä kuormittuneisuutta 60 ja 68 pisteen raja-arvoja hyödyntäen havaittiin, että äitien kokema lievä psyykkinen kuormittuneisuus oli yleisempää kuin isien kokema psyykkinen kuormittuneisuus. 60 pisteen raja-arvon perusteella huoltajien jakaumat poikkesivat toisistaan melkein merkitsevästi $\left(\chi_{(1)}^{2}=6,49\right.$, $\mathrm{p}=0,012)$. 68 pisteen raja-arvoa käytettäessä äitien ja isien psyykkisen kuormittuneisuuden jakaumat poikkesivat toisistaan erittäin merkitsevästi $\left(\chi_{(1)}^{2}=11,65, p=0,0006\right)$.

Enemmistö tutkimusaineiston äideistä (57 $\%, n=105)$ ja isistä (66 \%, $n=92)$ arvioi elämänlaatunsa vähintään hyväksi. Ainoastaan 6 prosenttia äideistä $(\mathrm{n}=11)$ ja 5 prosenttia isistä $(n=7)$ arvioi elämänlaatunsa huonoksi tai erittäin huonoksi. Huoltajien välillä ei havaittu tilastollisesti merkitseviä eroja. Sen 
Taulukko 2. Huoltajien psyykkinen kuormittuneisuus Mental Health Inventoryn (MHI-5) perusteella.

\begin{tabular}{|c|c|c|c|c|c|c|}
\hline & \multicolumn{2}{|c|}{$\begin{array}{l}\text { MHI-5 } \\
(52)\end{array}$} & \multicolumn{2}{|c|}{$\begin{array}{l}\text { MHI-5 } \\
(60)\end{array}$} & \multicolumn{2}{|c|}{$\begin{array}{l}\text { MHI-5 } \\
(68)\end{array}$} \\
\hline & $\begin{array}{c}\%(n) \\
{[95 \% \text { LV] }}\end{array}$ & $\underset{\text { (p-arvo) }}{\chi^{2} \text { (df) }}$ & $\begin{array}{c}\%(n) \\
{[95 \% \text { LV] }}\end{array}$ & $\begin{array}{c}\chi_{\text {(df) }}^{2} \\
\text { (p-arvo) }\end{array}$ & $\begin{array}{l}\%(n) \\
{[95 \% \text { LV] }}\end{array}$ & $\begin{array}{c}\chi_{\text {(df) }}^{2} \\
\text { (p-arvo) }\end{array}$ \\
\hline $\begin{array}{l}\text { Huoltajat } \\
\text { yhteensä }(n=320)\end{array}$ & $\begin{array}{c}14,4 \%(46) \\
{[ \pm 3,9 \%]}\end{array}$ & & $\begin{array}{c}27,8 \%(89) \\
{[ \pm 4,9 \%]}\end{array}$ & & $\begin{array}{c}40,0 \%(128) \\
{[ \pm 5,4 \%]}\end{array}$ & \\
\hline Äidit (n = 183) & $\begin{array}{c}16,9 \%(31) \\
{[ \pm 5,4 \%]}\end{array}$ & $\begin{array}{l}\chi^{2}=2,29_{(1)} \\
(p=0,15)\end{array}$ & $\begin{array}{c}33,3 \%(61) \\
{[ \pm 6,8 \%]}\end{array}$ & $\begin{array}{l}\chi^{2}=6,49_{(1)} \\
(p=0,012)\end{array}$ & $\begin{array}{c}48,1 \%(88) \\
{[ \pm 7,2 \%]}\end{array}$ & $\begin{array}{l}\chi^{2}=11,65_{(1)} \\
(p=0,0006)\end{array}$ \\
\hline Isät (n = 137) & $10,9 \%(15)$ & & $20,4 \%(28)$ & & $29,2 \%(40)$ & \\
\hline & [ $\pm 5,2 \%]$ & & [ \pm 6,8 \%] & & [ $\pm 7,6 \%]$ & \\
\hline
\end{tabular}

Taulukossa on esitetty psyykkisesti kuormittuneiden huoltajien prosenttiosuudet, havaintomäärät ja prosenttiosuuksille lasketut luottamusvälit.

Psyykkisesti kuormittuneiden huoltajien osuudet on laskettu kolmea eri katkaisukohtaa hyödyntäen: $\leq$ 52 pistettä, $\leq 60$ pistettä ja $\leq 68$ pistettä.

Äitien ja isien jakaumavertailut on toteutettu Pearsonin $\chi^{2}$-yhteensopivuustestillä ( $\mathrm{df}=$ vapausasteet).

Puuttuvat havainnot: äidit $(n=3)$, isät $(n=7)$.

sijaan huoltajien kokeman yksinäisyyden jakaumat poikkesivat toisistaan $\left(\chi_{(1)}^{2}=15,79\right.$, $p=0,001)$. Äideistä 31 prosenttia $(\mathrm{n}=57)$ ilmoitti tuntevansa joskus yksinäisyyttä, ja 13 prosenttia $(n=24)$ ilmoitti tuntevansa vähintään melko usein yksinäisyyttä. Isien osalta vastaavat osuudet olivat 21 prosenttia $(\mathrm{n}=$ 30) ja 4 prosenttia $(n=6)$. Äitien ilmoittama subjektiivinen ahdistuneisuus oli melko yleistä, sillä 42 prosenttia $(n=77)$ ilmoitti ahdistuvansa yleensä vähintään melko helposti. Isien osalta subjektiivista ahdistuneisuutta ilmaisi 14 prosenttia $(\mathrm{n}=19)$ vastanneista. Huoltajien subjektiivista ahdistuneisuutta kuvaavat jakaumat poikkesivat toisistaan tilastollisesti erittäin merkitsevästi $\left(\chi_{(1)}^{2}=31,25, p<0,001\right)$.

\section{Kontrollimuuttujien yhteys}

vanhemmuuteen liittyviin huoliin

Seuraavaksi muodostimme taulukossa 1 esitetyistä huoli-osioista summamuuttujan, jonka kokonaispistemäärä $(\min .=5$ pistettä; max. $=20$ pistettä) vaihteli tutkimusaineistossamme välillä 5-19 ( $M=10,20 ; 95 \% \mathrm{LV}=$ 9,87-10,53). Summamuuttujan reliabiliteetti oli kohtalaisen korkea (Cronbachin a $=0,77$ ). Yksittäiset huolta mittaavat osiot korreloivat hyvin summamuuttujan kokonaispistemäärän kanssa $[r=0,39-0,63]$. Jakauman visuaalisten tarkastelujen ja vinous- ja huipukkuuskertoimien perusteella normaalijakaumaoletukset olivat voimassa.

Hierarkkinen lineaarinen regressiomallinnus aloitettiin niin sanotun nollamallin avulla (mukana analyysissa ainoastaan vakiotermi ja virhetermit), jossa tarkasteltiin vanhemmuuteen liittyvien huolten varianssin jakautumista yksilö- ja ryhmätasoille. Nollamallin perusteella ryhmätason (perhe) varianssin samankaltaisuus oli aineistossamme heikkoa (sisäkorrelaatio $[\mathrm{ICC}]=0,09$ ): havainnon mukaan perheiden väliset erot selittivät melko vähän (9 \%) vanhemmuuteen liittyvien huolten kokonaisvaihtelusta. Seuraavaksi lisäsimme malliin kiinteäksi selittäväksi tekijäksi sen, oliko vastaajana lapsen äiti vai isä. Tulosten mukaan äidit $(M=11,1 ; 95 \% \mathrm{LV}=10,7-11,5)$ ilmaisivat 1,6-2,7 pistettä enemmän vanhemmuuteen liittyviä huolia kuin isät $(M=9,0 ; 95$ $\% \mathrm{LV}=8,5-9,4)$. Keskiarvojen ero oli tilastollisesti erittäin merkitsevä $(t=7,9, \mathrm{p}<0,001)$. Huoltajien välisten erojen huomiointi kasvatti merkittävästi myös sisäkorrelaatiota aineistossamme (ICC $=0,31)$. Toisin sanoen äitien ja isien keskinäisten erojen kontrolloinnin myötä vanhemmuuteen liittyvät huolet näyttäytyivät aineistossamme voimakkaammin ryhmä- 
tason ilmiönä. Huoltajien keskinäisten erojen kontrolloinnin jälkeen perheiden väliset erot selittivät jo 31 prosenttia vanhemmuuteen liittyvien huolten kokonaisvaihtelusta. Päävaikutusanalyysien perusteella lapsikohtaiset kontrollimuuttujat, kuten lapsen sukupuoli, ICD10-diagnoosiryhmä ja hoitohistoria, eivät sen sijaan olleet tilastollisesti merkitsevästi yhteydessä vanhemmuuteen liittyvien huolten vaihteluun. Analyysit tehtiin myös äitien ja isien aineistoille erikseen, mutta tilastollisesti merkitseviä päävaikutuksia ei havaittu.

\section{Vanhemmuuteen liittyvien huolten yhteys huoltajien psyykkiseen hyvinvointiin}

Lopuksi tarkastelimme vanhemmuuteen liittyvien huolten ja huoltajien psyykkistä hyvinvointia kuvaavien muuttujien lineaarista riippuvuutta (taulukko 3). Muuttujien keskinäiset korrelaatiot olivat tutkimusaineistomme äideillä ja isillä hyvin samankaltaisia. Voimakkaampi huoli vanhemmuudesta korreloi kohtalaisesti äitien $[r=-0,59]$ ja isien $[r=-0,53]$ ilmoittaman psyykkisen kuormittuneisuuden kanssa. Lisäksi kohonnut huoli vanhemmuudesta oli tilastollisesti merkitsevästi yhteydessä äitien $[r=0,50]$ ja isien $[r=0,36]$ heikompaan koettuun elämänlaatuun, voimakkaampaan yksinäisyyden tunteeseen $[r=0,33$ ja $0,27]$ ja koettuun subjektiiviseen ahdistuneisuuteen $[r=0,38$ ja 0,40$]$.

\section{Pohdinta}

Tutkimuksessa tarkasteltiin neuropsykiatrisesti oireilevien (5-12 vuotiaiden) lasten huoltajien psyykkistä hyvinvointia. Tutkimusaineisto koostui Kelassa kehitteillä oleviin perhelähtöisiin hoito-ohjelmiin ohjattujen lasten huoltajien itsearvioista. Enemmistölle hoitoon ohjatuista lapsista (75 \%) oli asetettu ADHDdiagnoosi. Lasten huoltajat toivat hoidon alkaessa esille erilaisia neuropsykiatrisesti oireilevan lapsen vanhempana toimimiseen liittyviä haasteita. Vanhemmuuteen liittyvien huolten vaihtelu oli aineistossamme kuitenkin melko suurta. Osalla vastaajista huoli omasta vanhemmuudesta oli korkeintaan lievää.
Voimakkaampi huoli oli yhteydessä äitien ja isien mielialaoireiluun, heikompaan elämänlaatuun, yksinäisyyteen ja ahdistuneisuuteen.

Tutkimuksemme mukaan huoltajat ilmaisivat etenkin syyllisyyden tunnetta (yleisyys $40 \%$ ja huolta omasta jaksamisestaan (yleisyys $30 \%$ ). Yleisväestölle suunnatuissa lapsiperhekyselyissä tämän tyyppisten huolten yleisyys on ollut noin 5-7 prosenttia (Perälä ym. 2011; Halme \&t Perälä 2014). Tutkimuksemme vahvistaa näkemystä, että merkittäviä vanhemmuuteen ja kasvatukseen liittyviä haasteita esiintyy etenkin psyykkisesti ja neuropsykiatrisesti oireilevien lasten huoltajilla (Karst \&t Van Hecke 2012). Tulosten perusteella vanhemmuuteen liittyvät huolenaiheet - kuten myös mielialaoireilu, yksinäisyys ja ahdistuneisuus - olivat johdonmukaisesti voimakkaampia äideillä kuin isillä. Tämä on havaittu myös kansainvälisissä meta-analyyseissa ja systemoiduissa katsauksissa, vaikkakin huoltajien keskinäiset erot eivät ole tulleet yksittäisissä tutkimuksissa aina yhtä selkeinä esiin (Theule ym. 2013). Toisaalta tuloksemme ja aikaisemmat tutkimukset osoittavat, että voimakkaampi vanhemmuuden stressi on yhteydessä äitien ja isien psyykkiseen kuormittuneisuuteen, kuten mielialaoireiluun ja ahdistuneisuuteen (Barlow ym. 2012).

Tutkimukset ovat osoittaneet, että lapsen tunteiden säätelyn ja käyttäytymisen pulmat eli uhmakkuus- ja käytösoireet lisäävät usein huoltajien psyykkistä kuormittuneisuutta, mikä saattaa heijastua kielteisesti lapsen ja huoltajan keskinäiseen vuorovaikutukseen (Deault 2010; Kanne \&t Mazurek 2011). Tässä tutkimuksessa lasten ICD-10-tautiluokituksen mukaisten diagnoosien ei kuitenkaan havaittu olevan yhteydessä vanhemmuuteen liittyvän huolen vaihteluun. Tämä saattaa selittyä osaksi sillä, että lapsen tunteiden säätelyn ja käyttäytymisen haasteet ovat tyypillisesti erityistason perheinterventioihin ohjaamisen taustalla (Daley ym. 2014; Sanders ym. 2014; Fabiano ym. 2015). Aiemmassa tutkimuksessa havaitsimmekin, että tunteiden säätelyn ja käyttäytymisen vaikeudet olivat melko yleisiä tutkimusaineistomme lapsilla (Vuori ym. 2017). Kansainvälisten katsausartikkelien pe- 
Taulukko 3. Vanhemmuuteen liittyvien huolten yhteys huoltajien psyykkiseen hyvinvointiin.

\begin{tabular}{|l|l|l|c|c|c|}
\hline $\begin{array}{l}\text { Huolisumma } \\
\text { (HU) }\end{array}$ & HU & MHI-5 & QoL & YKS & AHD \\
\hline $\begin{array}{l}\text { MHI-5 0-100 } \\
\text { (MHI-5) }\end{array}$ & - &,$- 59^{* *}$ &, $50^{* *}$ &, $33^{* *}$ &, $38^{* *}$ \\
\hline QoL &,$- 53^{* *}$ & - &,$- 73^{* *}$ &,$- 53^{* *}$ &,$- 52^{* *}$ \\
\hline $\begin{array}{l}\text { Yksinäisyys } \\
\text { (YKS) }\end{array}$ &, $36^{* *}$ &,$- 62^{* *}$ & - &, $37^{* *}$ &, $36^{* *}$ \\
\hline Ahdistuneisuus (AHD) &, $27^{* *}$ &,$- 34^{* *}$ &, $24^{* *}$ & - &, $27^{* *}$ \\
\hline
\end{tabular}

$* \mathrm{p} \leq 0,05 ; * * \mathrm{p} \leq 0,01$

Tulkintaohje: Äidit ( $n=181-183$ ) diagonaalin yläpuolella ja isät ( $n=137-141)$ diagonaalin alapuolella. $r \approx \pm 0,3$ (muuttujien välillä on heikko lineaarinen yhteys); $r \approx \pm 0,5$ (muuttujien välillä on kohtalainen lineaarinen yhteys); $r \approx \pm 0,7$ (muuttujien välillä on melko voimakas lineaarinen yhteys).

Huom. Suuremmat arvot merkitsevät voimakkaampaa vanhemmuuteen liittyvää huolta (HU), alhaisempaa psyykkistä kuormittuneisuutta (MHI-5), heikompaa koettua elämänlaatua (Quality of Life $=$ QoL), useammin koettua yksinäisyyttä (YKS) ja voimakkaampaa subjektiivista ahdistuneisuutta (AHD).

rusteella diagnoositarkastelua saattaisi edistää esimerkiksi lapsen oirekuvan haitta-asteen tarkempi määrittely (Theule ym. 2013).

Tutkimushavaintomme ovat ajankohtaisia myös lapsiperhepalvelujen kehittämisen näkökulmasta. Tulokset vahvistavat kotimaisen ADHD:n hoitosuosituksen ydinsanomaa: (a) koko perheen tukeminen on tärkeää neuropsykiatrisesti oireilevan lapsen hoitoa ja kuntoutusta suunniteltaessa, ja (b) lasten ja perheiden tukemisen tulee olla monimuotoista (ADHD: Käypä hoito -suositus 2017). Käytännössä lasten psykososiaalisessa hoidossa yhdistyvät sekä kotiin että kouluun suuntautuvat tukimuodot (Fabiano ym. 2015). Koska neuropsykiatrisesti oireilevilla päiväkoti- ja alakouluikäisillä lapsilla ilmenee usein myös tunteiden säätelyn ja käyttäytymisen pulmia (Kanne \& Mazurek 2011; Faraone ym. 2015), perhelähtöinen psykososiaalinen tuki on tutkimustiedon valossa aiheellista rakentaa kognitiivis-behavioraaliseen terapiaviitekehykseen pohjautuvan vanhempainohjauksen ympärille (Weisz Et Kazdin 2010; Menting ym. 2013; Daley ym. 2014; Pfiffner \& Haack 2014; Battagliese ym. 2015; Fabiano ym. 2015). Toisaalta huoltajien psyykkisen kuormittuneisuuden vaihtelusta seuraa, että tietyt toteutustavat saatta- vat soveltua tiettyyn tilanteeseen paremmin kuin toiset. Vanhempainohjaus tapahtuu kansainvälisissä käytännöissä usein ryhmämuotoisesti. Perheiden hyvinvoinnin tukemisessa on kuitenkin tärkeää pohtia myös erillisten lapsi- ja huoltajakohtaisten terapeuttisten elementtien hyödyntämistä, jotta esimerkiksi huoltajan mielialaoireilusta johtuviin yksilöllisiin tuen tarpeisiin pystytään vastaamaan laadukkaammin (Chronis ym. 2007; Barlow ym. 2012; Sanders ym. 2014; Lindhiem ym. 2016; Ng \&t Weisz 2016). Tämä on myös pohjoisamerikkalaisen MTA-tutkimuksen keskeisiä johtopäätelmiä (Hinshaw ym. 2015).

Psykososiaalisten perheinterventioiden kehitystyötä on tehty ja tehdään eri puolilla Suomea. Valitettavasti kokonaiskuva lapsiperheiden palvelujen järjestämisestä on epäselvä (Karjalainen ym. 2016). Tuoreiden tutkimusten perusteella erilaiset vanhempainohjaukseen perustuvat hoitomenetelmät soveltuvat hyvin myös pohjoismaiseen toimintaympäristöön (Bjørnebekk ym. 2015; Sourander ym. 2016). Tulevissa analyyseissa tarkastellaan tarkemmin sitä, missä määrin monimuotoinen perhekuntoutus vahvistaa huoltajien psyykkistä hyvinvointia kliinisesti rajatussa kohderyhmässä. 
Tiedon kerääminen molemmilta huoltajilta on tämän tyyppisessä tutkimusasetelmassa haaste ja johtaa herkästi siihen, että havaintoja jää puuttumaan esimerkiksi perhemuotojen moninaisuuden takia. Toinen merkittävä heikkous tutkimuksessamme on se, että vanhemmuuden stressin mittaaminen ei perustunut kansainvälisesti käytössä oleviin vakiintuneisiin mittareihin. Standardoidut mittarit ovat melko pitkiä ja usein maksullisia (Theule ym. 2013). Tutkimuksessa käyttämämme osiot ovat kuitenkin sisällöltään samankaltaisia kuin standardoitujen mittareiden osiot ja tarkastelevat yhtä vanhemmuuden stressin keskeistä osa-aluetta. Toisaalta vahvuus on se, että osiot ovat vertailukelpoisia kotimaisten lapsiperhekyselyjen kanssa (Perälä ym. 2011; Halme \&t Perälä 2014). Lisäksi osioista muodostettu summamuuttuja osoittautui reliaabeliksi. Lasten ICD-10-tautiluokituksen mukainen diagnoosiryhmittelymme puolestaan on todennäköisesti liian karkea. Yksittäinen diagnoosi, esimerkiksi ADHD, ei sinänsä kerro oireiden haitta-asteen vaihtelusta diagnoosiryhmän sisällä (Karst \&t Van Hecke 2012; Faraone ym. 2015). Kansainvälisissä tutkimuskäytännöissä oirekuvien vaihtelua on lisäksi pyritty täsmentämään lasten ADHD:n ja kliinisissä tutkimusaineistoissa ADHD:n yhteydessä yleisesti esiintyvien uhmakkuus- ja käytöshäiriöiden alatyypit huomioiden (Frick \&t Nigg 2012; Faraone ym. 2015). Aineiston pienestä koosta johtuen emme myöskään pystyneet kontrolloimaan tarkemmin keskeisiä interaktiovaikutuksia (esimerkiksi lapsen sukupuoli x ICD10-diagnoosi).

Yhteenvetona toteamme, että erityistason perhelähtöisiin hoito-ohjelmiin ohjattujen lasten huoltajien kokemat kasvatushaasteet ja psyykkinen kuormittuneisuus tulee tunnistaa. Kokonaisvaltaisen hoidon sisällön suunnittelussa ja terapeuttisten työskentelytapojen valinnassa on tärkeää huomioida voimakkaamman vanhemmuuteen liittyvän huolen laajaalainen yhteys huoltajien psyykkisen hyvinvoinnin heikentymiseen.
Tulosten merkitys: Neuropsykiatrisesti oireilevien lasten huoltajilla esiintyy erilaisia vanhempana toimimiseen liittyviä huolia. Merkittävä huoli vanhemmuudesta on yhteydessä huoltajien heikentyneeseen psyykkiseen hyvinvointiin kuten mielialaoireiluun. Perheiden hyvinvoinnin tukemisessa on tärkeää pohtia yksilö- ja perheterapeuttisten elementtien hyödyntämistä, jotta esimerkiksi huoltajan mielialaoireilusta johtuviin yksilöllisiin tuen tarpeisiin pystytään vastaamaan asianmukaisesti.

\section{Tiivistelmä}

Lähtökohdat. Tässä tutkimuksessa tarkasteltiin äitien ja isien vanhempana toimimiseen liittyviä huolia ja psyykkistä hyvinvointia tilanteessa, jossa lapsella esiintyy kliinisesti merkittävää neuropsykiatrista oireilua ja samanaikaisia tunteiden säätelyn ja käyttäytymisen pulmia.

Menetelmät. Tutkimusaineisto kerättiin perhelähtöisen hoito-ohjelman alkaessa. Hoito-ohjelma on tarkoitettu lapsille (5-12-vuotiaat), joille on asetettu neuropsykiatrinen diagnoosi, ja heidän perheenjäsenilleen. Poikkileikkausaineistoon perustuvassa kuvailevassa tutkimuksessa hyödynnettiin lasten huoltajille suunnattua aloitusvaiheen lomakekyselyä, johon vastasi 198 perhettä. Kyselyt toteutettiin varsinaisen hoitoprosessin alkaessa ja niihin vastasi 186 äitiä ja 144 isää.

Tulokset. Vanhemmuuteen liittyvien huolenaiheiden esiintyvyys oli yleistä tutkimusaineistossamme. Osalla äideistä (n. $30 \%$ ) ja isistä (n. $55 \%$ ) huoli vanhemmuudesta oli korkeintaan lievää. Huoltajien esille tuoma merkit- 
tävä huoli vanhemmuudesta ei vaihdellut esimerkiksi lapsen ICD-10-tautiluokituksen mukaisten diagnoosiryhmien mukaan. Huoltajien keskinäiset erot muodostuivat tärkeimmäksi tekijäksi aineistossamme. Äidit ilmaisivat enemmän vanhemmuuteen liittyviä huolenaiheita, mielialaoireita, yksinäisyyttä ja ahdistuneisuutta kuin isät. Toisaalta voimakkaampi huoli omasta vanhemmuudesta oli yhteydessä äitien ja isien mielialaoireiluun, heikompaan koettuun elämänlaatuun, yksinäisyyteen ja ahdistuneisuuteen.

Päätelmät. Neuropsykiatristen oireiden ja samanaikaisten tunne-elämän ja käyttäytymisen pulmien johdosta hoitoon ohjattujen lasten huoltajien kasvatushaasteet ja psyykkinen kuormittuneisuus tulee tunnistaa. Huoli omasta vanhemmuudesta on yhteydessä huoltajien heikentyneeseen psyykkiseen hyvinvointiin, mikä on tärkeää ottaa huomioon hoidon suunnittelussa ja toteutuksessa.

Avainsanat: aktiivisuuden ja tarkkaavuuden häiriö, Aspergerin oireyhtymä, vanhemmuus, psykologinen stressi, poikkileikkaustutkimus

\section{Abstract}

Parenting related worry and self-expressed psychological wellbeing among parents of children with neuropsychiatric disorders

Background. The present study examines parenting related worry and its association with psychological wellbeing in parents enrolled to family intervention. Multi-systemic intervention program is designed for children (aged 5-12) with neuropsychiatric disorders and possible comorbid disruptive behavior problems, and their family members.

Methods. We utilized pen-and-paper questionnaires in this correlational and cross-sectional study design. Altogether 186 mothers and 144 fathers from 198 families participated in the study.

Results. Parenting related concerns were relatively common in our study sample. Yet, for some parents the concerns were at most mild. Surprisingly, parenting related worry was not related to child-related factors (e.g. ICD10 diagnostic groups). Mothers expressed more parenting stress than fathers. Mothers were also more likely to express depressiveness, loneliness and anxiety when compared to fathers. Importantly, however, increased parenting related worry was associating with depressiveness, decreased quality of life, loneliness and anxiety among mothers and fathers in a similar way.

Conclusions. Children's neuropsychiatric disorders and possible comorbid disruptive behavior problems are associating with the increased parenting related concerns and difficulties. The relatively strong association between parenting related worry and decreased parental psychological wellbeing should be acknowledged when providing personalized care for children and their families.

Keywords: attention-deficit/hyperactivity disorder, Asperger's syndrome, parenting, psychological stress, crosssectional study 
Miika Vuori, VTT, sairaanhoitaja AMK, erikoistutkija, Kelan tutkimus, Kansaneläkelaitos

Annamari Tuulio-Henriksson, FT, neuropsykologian dosentti, tutkimusprofessori, Kansaneläkelaitos

Ilona Autti-Rämö, johtava ylilääkäri, tutkimusprofessori, Kansaneläkelaitos

\section{Lähteet}

ADHD (aktiivisuuden ja tarkkaavuuden häiriö). Käypä hoito-suositus (2017) Suomalaisen Lääkäriseura Duodecimin, Suomen Lastenneurologinen yhdistys ry:n, Suomen Lastenpsykiatriyhdistyksen ja Suomen Nuorisopsykiatrisen yhdistyksen asettama työryhmä. Helsinki: Suomalainen Lääkäriseura Duodecim (viitattu 11.9.2017). Saatavilla Internetissä: www.käypähoito.fi

Barlow J, Smailagic N, Huband N, ym. (2012) Groupbased parent training programmes for improving parental psychosocial health. Cochrane Database Syst Rev 6:CD002020.

Battagliese G, Caccetta M, Luppino OI, ym. (2015) Cognitive-behavioral therapy for externalizing disorders: a meta-analysis of treatment effectiveness. Behav Res Ther 75, 60-71.

Bearss K, Burrell TL, Stewart LM, Scahill L (2015) Parent training in autism spectrum disorder: What's in a name? Clin Child Fam Psychol Rev 18, 2, 170-82.

Bjørnebekk G, Kjøbli J, Ogden T (2015) Children with conduct problems and co-occurring ADHD: behavioral improvements following parent management training. Child Fam Behav Ther 37, 1, 1-19.

Chronis AM, Lahey BB, Pelham WE Jr, ym. (2007) Maternal depression and early positive parenting predict future conduct problems in young children with attention-deficit/hyperactivity disorder. Dev Psychol 43, 1, 70-82.

Daley D, van der Oord S, Ferrin M, ym. (2014) Behavioral interventions in attention-deficit/hyperactivity disorder: a meta-analysis of randomized controlled trials across multiple outcome domains. J Am Acad Child Adolesc Psychiatry 53, 8, 835-47.

Deater-Deckard K (1998) Parenting stress and child adjustment: some old hypotheses and new questions. Clin Psychol-Sci Pr 5, 314-32.

Deault LC (2010) A Systematic Review of Parenting in Relation to the Development of Comorbidities and Functional Impairments in Children with Attention-Deficit/Hyperactivity disorder (ADHD). Child Psychiatry Hum Dev 41, 2, 168-92.

Ellonen N (2008) Monitasoanalyysit ja niiden soveltaminen sosiaalitieteissä. Janus 14, 2, 127-138.
Fabiano GA, Schatz NK, Aloe AM, ym. (2015) A systematic review of meta-analyses of psychosocial treatment for attention-deficit/hyperactivity disorder. Clin Child Fam Psychol Rev 18, 1, 77-97.

Faraone S, Asherson P, Banaschewski T, ym. (2015) Attention-deficit/hyperactivity disorder. Nat Rev Dis Primers 6, 1.

Frick PJ, Nigg JT (2012) Current issues in the diagnosis of attention deficit hyperactivity disorder, oppositional defiant disorder, and conduct disorder. Annu Rev Clin Psychol 8, 77-107.

Furlong M, McGilloway S, Bywater T, ym. (2012) Behavioural and cognitive-behavioural group-based parenting programmes for early-onset conduct problems in children aged 3 to 12 years. Cochrane Database Syst Rev 2:CD008225.

Garson GD (2013) Hierarchical linear modeling - guide and applications. London: SAGE.

Gladstone G, Parker G (2003) What's the use of worrying? Its function and its dysfunction. Aust $\mathrm{N} \mathrm{Z}$ J Psychiatry 37, 3, 347-54.

Halme N, Perälä ML (2014) Lapsiperheiden huoli ja avunsaanti. Kirjassa: Lammi-Taskula J, Karvonen S (toim.) Lapsiperheiden hyvinvointi 2014. Terveyden ja hyvinvoinnin laitos, Helsinki, 216-27.

Hayes SA, Watson SL (2013) The Impact of Parenting Stress: A Meta-analysis of Studies Comparing the Experience of Parenting Stress in Parents of Children With and Without Autism Spectrum Disorder (2013) J Autism Dev Disord 43, 3, 629-42.

Hinshaw SP, Arnold LE, MTA Cooperative Group (2015) ADHD, multimodal treatment, and longitudinal outcome: evidence, paradox, and challenge. Wiley Interdiscip Rev Cogn Sci 6, 39-52.

Johnston C, Mash EJ (2001) Families of children with attention-deficit/hyperactivity disorder: review and recommendations for future research. Clin Child Fam Psychol Rev 4, 3, 183-207.

Kanne SM, Mazurek MO (2011) Aggression in children and adolescents with ASD: prevalence and risk factors. J Autism Dev Disord 41, 7, 926-937.

Karjalainen P, Santalahti P, Sihvo S (2016) Vaikuttavatko vanhemmuustaitoja tukevat ohjelmat lapsen käytöshäiriöiden ja -ongelmien ehkäisyssä ja vähentämisessä? Duodecim 132, 3, 967-74.

Karst JS, Van Hecke AV (2012) Parent and family impact of autism spectrum disorder: a review and proposed model for intervention evaluation. Clin Child Fam Psychol Rev 15, 3, 247-77.

Kawabata Y, Alink LRA, Tseng WL, ym. (2011) Maternal and paternal parenting styles associated with relational aggression in children and adolescents: A conceptual analysis and meta-analytic review. Dev Rev 31, 4, 240-78. 
Kelly MJ, Dunstan FD, Lloyd K, Fone DL (2008) Evaluating cutpoints for the MHI-5 and MCS using the GHQ-12: a comparison of five different methods. BMC Psychiatry 8, 10.

Kippola-Pääkkönen A, Härkäpää K, Järvikoski A, Autti-Rämö I (2016) Sopeutumisvalmennuskursseille osallistuvien lasten vanhempien arvioita hyvinvoinnista, toimintakyvystä ja kurssiodotuksista. Kuntoutus 1, 6-21.

Lindhiem 0, Bennett CB, Orimoto TE, Kolko DJ (2016) A meta-analysis of personalized treatment goals in psychotherapy: a preliminary report and call for more studies. Clin Psychol 23, 2, 165-176.

March JS, Silva SG, Compton S, ym. (2005) The case for practical clinical trials in psychiatry. Am J Psychiatry 162, 5, 836-846.

Menting ATA, Orobio de Castro B, Matthys W (2013) Effectiveness of the Incredible Years parent training to modify disruptive and prosocial child behavior: A meta-analytic review. Clin Psychol Rev 33, 8, 901-13.

Murto J, Kaikkonen R, Pentala-Nikulainen 0, ym. (2017) Aikuisten terveys-, hyvinvointi- ja palvelututkimus ATH:n perustulokset 2010-2017. Verkkojulkaisu: www.thl.fl/ath

Ng MY, Weisz JR (2016) Annual Research Review: Building a science of personalized intervention for youth mental health. J Child Psychol Psychiatry 57, 3, 216-36.

Pfiffner LJ, Haack LM (2014) Behavior management for school-aged children with ADHD. Child Adolesc Psychiatr Clin N Am 23, 4, 731-746.

Perälä ML, Salonen A, Halme N, Nykänen S (2011) Miten lasten ja perheiden palvelut vastaavat tarpeita? Vanhempien näkökulma. Raportti 36. Terveyden ja hyvinvoinnin laitos, Helsinki.

Raitasalo R (2007) Mielialakysely: Suomen oloihin Beckin depressiokyselyn pohjalta kehitetty masennusoireilun ja itsetunnon kysely. Kela, Helsinki.

Sanders MR, Kirby JN, Tellegen CL, Day JJ (2014) The Triple P-Positive Parenting Program: A systematic review and meta-analysis of a multi-level system of parenting support. Clin Psychol Rev 34, 4, 337-57.

Sourander A, McGrath PJ, Ristkari T, ym. (2016) Internet-assisted parent training intervention for disruptive behavior in 4-year-old children. JAMA Psychiatry 73, 4, 378-87.

Theule J, Wiener J, Tannock R, Jenkins JM (2013) Parenting Stress in Families of Children with ADHD: A Meta-Analysis. J Emot Behav Disord 21, 1, 3-17.

Vester Thorsen S, Rugulies R, Hjarsbech PU, Bjorner JB (2013) The predictive value of mental health for long-term sickness absence: the Major Depression Inventory (MDI) and the Mental Health Inventory (MHI-5) compared. BMC Medical Research Methodology 13, 115.

Vuori M, Tuulio-Henriksson A, Autti-Rämö I (2015) Monimuotoisen neuropsykiatrisen perhekuntoutuksen seurantatutkimus. Tutkimusprotokolla. Työpapereita 82. Kelan tutkimusosasto, Kansaneläkelaitos.

Vuori M, Autti-Rämö I, Junttila N, ym. (2017) Discrepancies between self- and adult-perceptions of social competence in children with neuropsychiatric disorders. Child Care Health Dev 43, 5, 670-78.

Weisz JR, Kazdin AE (2010) Evidence-based psychotherapies for children and adolescents. London: The Guildford Press.

Yamazaki S, Fukuhara S, Green J (2005) Usefulness of five-item and three-item Mental Health Inventories to screen for depressive symptoms in the general population of Japan. Health Quol Life Outcomes 3, 48.

Östberg M, Hagekull B (2000) A Structural Modeling Approach to the Understanding of Parenting Stress. J Clin Child Psychol 29, 4, 615-25. 